\title{
Evaluadores 2018 \\ Agradecimiento Editorial
}

Como toda revista científica que utiliza el sistema de pares evaluadores, la revista Psykhe recibe la valiosa colaboración de numerosos académicos e investigadores de instituciones de variadas latitudes. Todos/as ellos/as aceptan desinteresadamente evaluar en el sistema de doble ciego los artículos que se les envían para su revisión. Nuestro equipo editorial reconoce la labor de cada uno de ellos/as, junto con la de los/as miembros del Comité Editorial.

Sin la contribución de los evaluadores, mantener una revista de calidad sería imposible.

A continuación, se señalan los nombres de los evaluadores que contribuyeron durante el año 2018. Pensamos que la calidad de la revista, se debe en gran medida al aporte de tiempo y experticia de quienes aparecen nombrados.

Equipo Editorial Psykhe

\section{Reviewers 2018 \\ Editorial Acknowledgment}

Like every scientific journal that uses the peer-review system, Psykhe receives the valuable collaboration of several academics and researchers from institutions of different latitudes. All of them accept unselfishly to evaluate in the double-blind system the articles that are sent to them for their review. Our editorial team recognizes the work of each of them, along with that of the Editorial Committee members.

Without the contribution of the reviewers, maintaining a journal of quality would be impossible.

The names of the reviewers who contributed during 2018 are indicated below. We think that the quality of the journal, to a large extent, depends on the contribution of time and expertise from those who are named.

Editorial Team Psykhe

Guadalupe Acle

Carolina Aguilera

Daniel Alarcón

José Andrés Alcalá

Jaime Alfaro

Francisco Alonso

Yolanda Andreu

Nicolás Angelcos

Svenska Arensburg

Patricio Arias

Rodrigo Asún

Susana Azzollini

Gonzalo Bacigalupe

Joaquín Bahamondes

Ana María Beltrán

Oriana Bernasconi

Héctor Berroeta

Gerd Bohner

Angelo Brandelli

Carolina Bringas-Molleda

María Elisa Calcagni

José Enrique Callejas

Manuel Cárdenas

Laís Carvallo

Marcelo Casals

Mariano Castellaro

Jorge Castillo

María Isabel Castillo

Diego Castro

Franciso Ceric
Franciso Ceric

Enrique Chaux

Soledad Concha

Olga Cuadros

Zamara Cuadros

María Alejandra Dellacasa

Patricio De La Cuadra

Beatriz Diuk

Paula Domínguez

Claudio Duarte

Michele Dufey

Orieta Echávarri

Yonatan Encina

Jordi Escartín

José Pablo Escobar

Adriana Espinoza

Victoria Espinoza

Carla Fardella

Ainzara Favini

Rodrigo Ferrero

Ana Figueiredo

Víctor Figueroa

Paulina Freire

Iris Xóchitl Galicia

Bárbara García

Sebastián Garrido

Jorge Gato

Fabiola Gómez

Xose Antón Gómez

Antoni Gomila
Valeska Grau

Raúl Gutiérrez-Fresneda

Mónica Guzmán

Andrés Haye

Cristóbal Hernández

Evelyn Hevia

Cristian Iturriaga

Francisco Jeanneret

Arlett Krause

José María León

María Rosa Lissi

Pablo Livacic

Antonio López

María Paz Maino

Francesca Manzi

Pablo Marassi

Moisés Mebarak

Juan Carlos Mendoza

Alejandra Meneses

Belén Mesurado

Claudia Miranda

Danilo Moggia

Agustín Molina

Verónica Monreal

Germán Morales

Carla Muñoz

Javiera Navarro

Barbara Olivares

Pelusa Orellana

Jorge Palacio
Daniel Party

Víctor Pedrero

Claudia Pérez-Salas

Felipe Porflitt

Vanetza Quezada

Darinka Radovic

Camila Rasse

María Isabel Reyes Espejo

Pedro Reynaga

Cristina Richaud

Andrea Rihm

Carolina Rocha

Juliana Rodríguez

Francisca Román

Miguel Rosello

Natascha Roth

Joan Rue

Paula Samper

Alveiro Sánchez

Diego Sánchez

Noelia Sánchez

Matías Sanfuentes

Antonio Stecher

Marcela Tenorio

Eriona Thartori

David Torres

Sergi Varela

Salvador Vargas

Francisco Vidal 